Research Article

\title{
Determination of Halogens by Ion Chromatography in Edible Mushrooms after Microwave-Induced Combustion for Sample Preparation
}

\author{
Gilberto Silva Coelho Junior ${ }^{D},{ }^{1}$ Filipe Soares Rondan ${ }^{D},{ }^{1}$ Carla Andrade Hartwig (DD, \\ Rafael Francisco Santos $\mathbb{D}^{2},{ }^{2}$ Paola Azevedo Mello $\mathbb{D}^{2},{ }^{2}$ and Marcia Foster Mesko $\mathbb{D}^{1}$ \\ ${ }^{1}$ Centro de Ciências Químicas, Farmacêuticas e de Alimentos, Universidade Federal de Pelotas, Capão do Leão 96160-000, \\ RS, Brazil \\ ${ }^{2}$ Departamento de Química, Universidade Federal de Santa Maria, Santa Maria 97105-900, RS, Brazil
}

Correspondence should be addressed to Marcia Foster Mesko; marciamesko@yahoo.com.br

Received 30 July 2021; Revised 20 September 2021; Accepted 6 October 2021; Published 31 October 2021

Academic Editor: Adam Voelkel

Copyright $\odot 2021$ Gilberto Silva Coelho Junior et al. This is an open access article distributed under the Creative Commons Attribution License, which permits unrestricted use, distribution, and reproduction in any medium, provided the original work is properly cited.

\begin{abstract}
In this study, the microwave-induced combustion (MIC) method was evaluated for the sample preparation of the most consumed mushroom species in Brazil (Champignon, Shiitake, and Shimeji) and further halogen determination by ion chromatography (IC). For this, sample mass, combustion aid mass, and absorbing solution $\left(\mathrm{H}_{2} \mathrm{O}\right.$ and $50 \mathrm{mmol} \cdot \mathrm{L}^{-1}, 100 \mathrm{mmol} \cdot \mathrm{L}^{-1}$, or $150 \mathrm{mmol} \cdot \mathrm{L}^{-1} \mathrm{NH}_{4} \mathrm{OH}$ ) were evaluated. Bromine and iodine concentrations, determined by IC, were lower than the limits of detection (LODs, Br: $6 \mathrm{mg} \cdot \mathrm{kg}^{-1}$ and I: $24 \mathrm{mg} \cdot \mathrm{kg}^{-1}$ ). Inductively coupled plasma mass spectrometry (ICP-MS) was also used for Br and I determination, and the LODs were lower (Br: $0.066 \mathrm{mg} \cdot \mathrm{kg}^{-1}$ and I: $0.014 \mathrm{mg} \cdot \mathrm{kg}^{-1}$ ) than those obtained by IC. Concentrations of $\mathrm{Cl}$, obtained by IC, ranged from $523 \mathrm{mg} \cdot \mathrm{kg}^{-1}$ to $13053 \mathrm{mg} \cdot \mathrm{kg}^{-1}$ with LOD of $40 \mathrm{mg} \cdot \mathrm{kg}^{-1}$. In turn, Br and I concentrations, obtained by ICP-MS, ranged from $2.49 \mathrm{mg} \cdot \mathrm{kg}^{-1}$ to $5.50 \mathrm{mg} \cdot \mathrm{kg}^{-1}$ and from $<0.014 \mathrm{mg} \cdot \mathrm{kg}^{-1}$ to $0.047 \mathrm{mg} \cdot \mathrm{kg}^{-1}$, respectively. Fluorine concentrations, determined by IC, were always lower than LOD $\left(23 \mathrm{mg} \cdot \mathrm{kg}^{-1}\right)$. The trueness of the proposed methods was evaluated by recovery tests using standard solutions and a reference material (RM NIST 8435). When using the standard solution, recoveries ranged from $95 \%$ to $103 \%$ for halogen determination by IC and from $105 \%$ to $109 \%$ for Br and I determination by ICPMS. When using the RM, recoveries of $102 \%$ for $\mathrm{Cl}$ by IC and of $87 \%$ and $86 \%$ for $\mathrm{Br}$ and I by ICP-MS, respectively, were obtained.
\end{abstract}

\section{Introduction}

Mushrooms are foods that have been appreciated by humanity since ancient times because people believed in their high nutritional value and medicinal potential. Nowadays, mushrooms still have great use as spices in culinary dishes, whose consumption has been increased due to the low calories and high amounts of proteins, vitamins, and minerals $[1,2]$.

Approximately 2000 edible species of mushrooms are known. However, only about 25 are commercially grown. Among the most cultivated and consumed species in Brazil are the Champignon (Agaricus), Shiitake (Lentinula), and
Shimeji (Pleurotus) [3]. Although the production of mushrooms in Brazil is about 12,000 tons year ${ }^{-1}$, the per capita consumption in the country is about $160 \mathrm{~g} \mathrm{year}^{-1}$. This consumption is low when compared to European countries such as France, Italy, and Germany, which have an annual per capita consumption higher than $2 \mathrm{~kg}$, while Asian countries such as China and South Korea consume more than $8 \mathrm{~kg}$ of mushrooms annually [4].

Despite of the high nutritional values of mushrooms, these foods are sources of macronutrients and micronutrients, such as the halogens $[5,6]$. In this sense, because some elements can cause health hazards when in inadequate amounts in the organism, it is necessary to know about their 
concentrations in foods. Thus, in view of their high consumption worldwide, halogens in mushrooms should be monitored.

Among the halogens, bromine $(\mathrm{Br})$ is an essential element that acts as cofactor for the collagen IV formation [7]. However, there are reports in the literature indicating that, depending on the species to which the $\mathrm{Br}$ is ingested, it may present carcinogenic effects. Moreover, $\mathrm{Br}$ can change the functioning of the thyroid gland, affecting the transport of iodine (I) to the gland, culminating in parallel disorders $[8,9]$.

Chlorine $(\mathrm{Cl})$ is an important mineral for the human body since it participates in several vital functions. In general, this element controls the anion-cation balance of the blood osmotic pressure and the balance of body water. Also, $\mathrm{Cl}$ participates in the nutrient transport across membranes and in regulation of membrane permeability of various tissues, as well as being part of the composition of various enzymes [10].

Fluorine $(\mathrm{F})$ is related with the prevention of dental caries and improves the oral and bone health. However, the excessive ingestion may cause dental and skeletal fluorosis, leading to increased probability of bone fractures [11].

In turn, I is essential for the synthesis of thyroid hormones, regulating a variety of important physiological functions in the body, mainly related to the development, growth, metabolic processes, and cellular oxidation $[10,12,13]$.

Thus, $\mathrm{Br}, \mathrm{Cl}, \mathrm{F}$, and I determination in mushrooms is important to ensure the ingestion of safe levels of these elements. However, only a few studies in the literature performed halogen determination in mushrooms, and most of them use techniques not available in routine laboratories, such as instrumental neutron activation analysis (INAA) and energy dispersive X-ray fluorescence (EDXRF) $[6,14,15]$.

In this sense, as alternatives for halogen determination, some analytical techniques have been widely used, such as inductively coupled plasma mass spectrometry (ICP-MS), inductively coupled plasma optical emission spectrometry (ICP-OES), and ion chromatography (IC). Among these analytical techniques, the IC technique with conductivity detection could be highlighted due to its relatively lower cost in relation to analysis, acquisition, and instrument maintenance, and it allows the determination of $\mathrm{Br}, \mathrm{Cl}, \mathrm{F}$, and $\mathrm{I}$ in a single chromatography run, while the determination of $\mathrm{F}$ by ICP-OES or ICP-MS is not possible to be performed by conventional ways $[16,17]$.

To perform analyses by IC technique, the sample must be introduced into the system as a solution. However, the complete digestion of mushrooms is not a simple task, considering their relatively high concentration of ash and crude protein [5, 18]. Furthermore, acid wet digestion methods are not suitable for further determination of halogens $[19,20]$. Using acid solution for sample digestion and further halogen determination, there is a risk of analytes loss. Thus, the microwave-induced combustion (MIC) method can be considered a good alternative for the sample preparation of mushrooms, due to the possibility of combustion of organic matter and analytes recovery in a suitable absorbing solution (water or alkaline solutions) [19, 21-27]. Although the MIC method has been successfully applied for the digestion of organic samples for subsequent determination of halogens, there are no reports in the literature of its use for the digestion of mushrooms.

Therefore, in this study, a method for digestion of mushrooms using MIC and further determination of $\mathrm{Br}, \mathrm{Cl}$, $\mathrm{F}$, and I by IC was proposed. In addition, $\mathrm{Br}$ and I concentrations were also determined by ICP-MS, using the sample preparation conditions selected in the proposed method.

\section{Materials and Methods}

2.1. Samples. Mushrooms produced in the state of Rio Grande do Sul, Brazil, were purchased in a local market in natural form. Three species of mushrooms, Champignon (brown and white), Shiitake, and Shimeji, were acquired, totalizing four samples. White Champignon sample was arbitrarily chosen for optimization of the method conditions. The samples that were not used in the optimization tests were further digested using the selected conditions. Prior to the analyses, the samples were individually dried at $65 \pm 5^{\circ} \mathrm{C}$ for $36 \mathrm{~h}$. A reference material (RM), from the National Institute of Standards and Technology (NIST 8435, whole milk powder), was used as a spike to evaluate the trueness of the proposed method.

2.2. Instrumentation. Samples and reagents were weighed using an analytical balance (model AY220, Shimadzu, Philippines), with resolution of $0.0001 \mathrm{~g}$. A food processor (model Multi Pro All in One 2, Philco, Brazil) and a conventional oven (model 400/2ND, DeLeo, Brazil) were used to grind and dry the samples, respectively. Ultrapure water $(18.3 \mathrm{M} \Omega \cdot \mathrm{cm})$ used in this study was obtained from a purification system (model Mega Up, Megapurity, South Korea).

Sample preparation by MIC method was performed using a microwave oven (model Multiwave $3000^{\circledR}$, Anton Paar, Austria). This system was equipped with eight high pressure quartz vessels (volume of $80 \mathrm{~mL}$, maximum temperature and pressure of $280^{\circ} \mathrm{C}$ and $80 \mathrm{bar}$, respectively) and quartz devices used as sample holder. For the decontamination and further drying of the discs of filter paper and lowdensity polyethylene (LDPE) films used in the MIC process, an ultrasonic bath $(40 \mathrm{kHz}, 155 \mathrm{~W}$, model USC-1800 A, Unique, Brazil) and a class 100 laminar flow hood (model CSLH-12, Veco, Brazil) were used. For the $\mathrm{pH}$ measurement, digital equipment (model mPA-210, MS Tecnopon, Brazil) was used.

Halogen determination was carried out using an ion chromatograph (model 861 Advanced Compact IC, Metrohm, Switzerland), equipped with an anion self-regeneration suppressor and conductivity detector. Furthermore, $\mathrm{Br}$ and I determination was carried out using an inductively coupled plasma mass spectrometer (model NexION 300X, Perkin-Elmer, Canada) equipped with a concentric 
nebulizer (Meinhard Associates, USA), a cyclonic spray chamber (Glass Expansion Inc., Australia), and a quartz torch with a quartz injector tube $(2 \mathrm{~mm}$ i.d.). The operating conditions for the IC and ICP-MS are shown in Table 1.

2.3. Reagents. All solutions and dilutions were prepared using ultrapure water, and all reagents were of analytical grade or higher purity. Solutions of $\mathrm{NH}_{4} \mathrm{OH}$ used as absorbing solution were prepared from commercial $\mathrm{NH}_{4} \mathrm{OH}$ solution ( $27 \% \mathrm{~m} / \mathrm{m} \mathrm{NH}_{3}$, Synth, Brazil). Ammonium nitrate solution $\left(6 \mathrm{~mol} \mathrm{~L}^{-1}\right)$, used as igniter and/or as combustion aid by MIC, was prepared by dissolution of the solid reagent (Merck, Germany) in water.

Decontamination of the quartz vessels and holders used in MIC method was performed using $6 \mathrm{~mL}$ of $65 \%(\mathrm{~m} / \mathrm{m})$ $\mathrm{HNO}_{3}$ (Vetec, Brazil) followed by $6 \mathrm{~mL}$ of ultrapure water, according to previous works [28-30]. Small discs (approximately $12 \mathrm{mg}, 15 \mathrm{~mm}$ of diameter) of filter paper $(0.5 \%$ ash content, Qualy, J Prolab, Brazil) were used in combustion step, and LDPE films $(80 \times 80 \mathrm{~mm})$ were used to wrap the samples [31].

The mobile phase used during IC analyses $\left(3.2 \mathrm{mmol} \mathrm{L}^{-1}\right.$ $\mathrm{Na}_{2} \mathrm{CO}_{3}$ and $1.0 \mathrm{mmol} \mathrm{L}^{-1} \mathrm{NaHCO}_{3}$ ) was prepared by the dissolution of corresponding salts (Synth) in water. Sulfuric acid solution $\left(0.2 \mathrm{~mol} \mathrm{~L}^{-1}\right)$, prepared from 95 to $99 \%(\mathrm{~m} / \mathrm{m})$ $\mathrm{H}_{2} \mathrm{SO}_{4}$ (Merck), was used for sodium suppression in the system regeneration.

Argon with purity of $99.996 \%$ (White Martins, Brazil) was used for plasma generation and nebulization and as auxiliary gas for $\mathrm{Br}$ and I determination by ICP-MS. The purity of the $\mathrm{O}_{2}$ used for the vessels pressurization in MIC method was 99.6\% (White Martins).

For the analyte determination by IC or ICP-MS, as well as recoveries tests, solutions were prepared by dilution of stock solutions of $\mathrm{Br}^{-}, \mathrm{Cl}^{-}, \mathrm{F}^{-}$, and $\mathrm{I}^{-}$which were prepared by dissolution of the respective salts of $\mathrm{KBr}$ (Merck), $\mathrm{KCl}$ (Synth), NaF (Synth), and KI (Merck), respectively, in ultrapure water. The calibration ranges for IC determination were from $0.1 \mathrm{mg} \mathrm{L}^{-1}$ to $1.0 \mathrm{mg} \mathrm{L}^{-1}$ for $\mathrm{Br}^{-}, \mathrm{Cl}^{-}, \mathrm{F}^{-}$, and $\mathrm{I}^{-}$. For ICP-MS determination, the calibration range was from $1 \mu \mathrm{g} \mathrm{L}^{-1}$ to $10 \mu \mathrm{g} \mathrm{L}^{-1}$ for $\mathrm{Br}$ and $0.1 \mu \mathrm{g} \mathrm{L}^{-1}$ to $1.0 \mu \mathrm{g} \mathrm{L}^{-1}$ for I.

2.4. Sample Preparation by the MIC Method. In initial studies by MIC, powdered sample of White Champignon was weighed and wrapped with a LDPE film. The LDPE film was then sealed by heating, and the excess of film was removed (film mass final used was approximately $30 \mathrm{mg}$ ). Aiming at better decompositions of the samples, $6 \mathrm{~mol} \mathrm{~L}^{-1} \mathrm{NH}_{4} \mathrm{NO}_{3}$ was mixed with the samples, taking into account that preview study in the literature used this reagent as combustion aid [31]. A small disc of filter paper was placed on the base of a quartz holder. The filter paper was moistened with $50 \mu \mathrm{L}$ of $6 \mathrm{~mol} \mathrm{~L}^{-1} \mathrm{NH}_{4} \mathrm{NO}_{3}$ (igniter solution) and the wrap containing the sample was placed on the paper. The quartz holder was introduced inside the quartz vessel previously charged with $6 \mathrm{~mL}$ of absorbing solution. Ultrapure water and $50 \mathrm{mmol} \mathrm{L}^{-1}$ to $150 \mathrm{mmol} \mathrm{L}^{-1} \mathrm{NH}_{4} \mathrm{OH}$ solutions were evaluated for analytes absorption. After closing, the vessels were positioned on the rotor, pressurized with 20 bar of $\mathrm{O}_{2}$, and the rotor was placed inside the microwave oven.

The microwave heating program used for sample preparation by MIC was $1400 \mathrm{~W}$ for $5 \mathrm{~min}$ (combustion and reflux steps) and, in the sequence, $0 \mathrm{~W}$ was applied for $20 \mathrm{~min}$ (cooling step) [31, 32]. After the procedure, the gases and vapors of each vessel were released and digests were transferred to volumetric flasks, being diluted with ultrapure water up to $25 \mathrm{~mL}$. The analytes determination was performed by the analytical techniques previously described.

The trueness of the optimized proposed method was evaluated by recovery tests using standard solutions containing all analytes and by analysis of a $\mathrm{RM}$ for $\mathrm{Br}$ and $\mathrm{I}$. The recovery tests were performed by the addition of a standard solution to the sample (selected mass) before MIC digestion. Thus, the solution was prepared considering that the added volume represented $50 \%$ of the concentrations of the analytes present in the samples. For the analytes not detected in the samples, 1.5 times the limit of quantification (LOQ) were added. Moreover, a similar recovery test was performed by combustion of a mixture containing $50 \mathrm{mg}$ of RM NIST 8435 and $500 \mathrm{mg}$ of the mushroom sample. After, the proposed method was applied for other samples evaluated in this study. The halogen determination in digests from MIC was performed by IC technique. In addition, the same digests were also analyzed by ICP-MS for Br and I determination.

All results were statistically evaluated by one-way analysis of variance (ANOVA) followed by the Tukey test or Student's $t$-test (confidence level of 95\%) using GraphPad InStat version 3.00 computer software package (GraphPad, USA).

\section{Results and Discussion}

3.1. Evaluation of the Maximum Mass of Mushroom Digested by MIC. For this evaluation, water was used as absorbing solution considering that the focus of this study was only to verify the aspect of the sample after digestion. Thus, initially, $200 \mathrm{mg}$ of dry sample mass was digested by MIC, and after each subsequent test, $100 \mathrm{mg}$ of sample was increased. During this evaluation, in addition to the aspect of the digests, the maximum pressure reached by the system was monitored. When evaluating sample masses from $200 \mathrm{mg}$ to $400 \mathrm{mg}$, colorless digests and clean quartz holders and vessels were observed, indicating a suitable digestion. However, for digestion of $500 \mathrm{mg}$ of sample, an unsuitable digestion was obtained, characterized by the presence of residues in the sample holder and a yellowish solution. As form of increasing the sample mass efficiently digested by MIC, the use of a combustion aid was evaluated. Thus, $50 \mu \mathrm{L}$ of $6 \mathrm{~mol} \mathrm{~L}^{-1} \mathrm{NH}_{4} \mathrm{NO}_{3}$ (combustion igniter solution) was mixed to $500 \mathrm{mg}$ of sample and a suitable digestion was obtained. Beyond, when we performed this evaluation, the maximum pressure observed in the system was 39 bar, which correspond to $49 \%$ of the maximum pressure ( 80 bar) recommended by manufacturer of the microwave oven. On the other hand, when higher sample mass $(600 \mathrm{mg}$ with $50 \mu \mathrm{L}$ of $6 \mathrm{~mol} \mathrm{~L}^{-1} \mathrm{NH}_{4} \mathrm{NO}_{3}$ ) was evaluated, unsuitable digestion was obtained. It is important to mention that the use 
TABle 1: Operational conditions for halogen determination by IC and by ICP-MS.

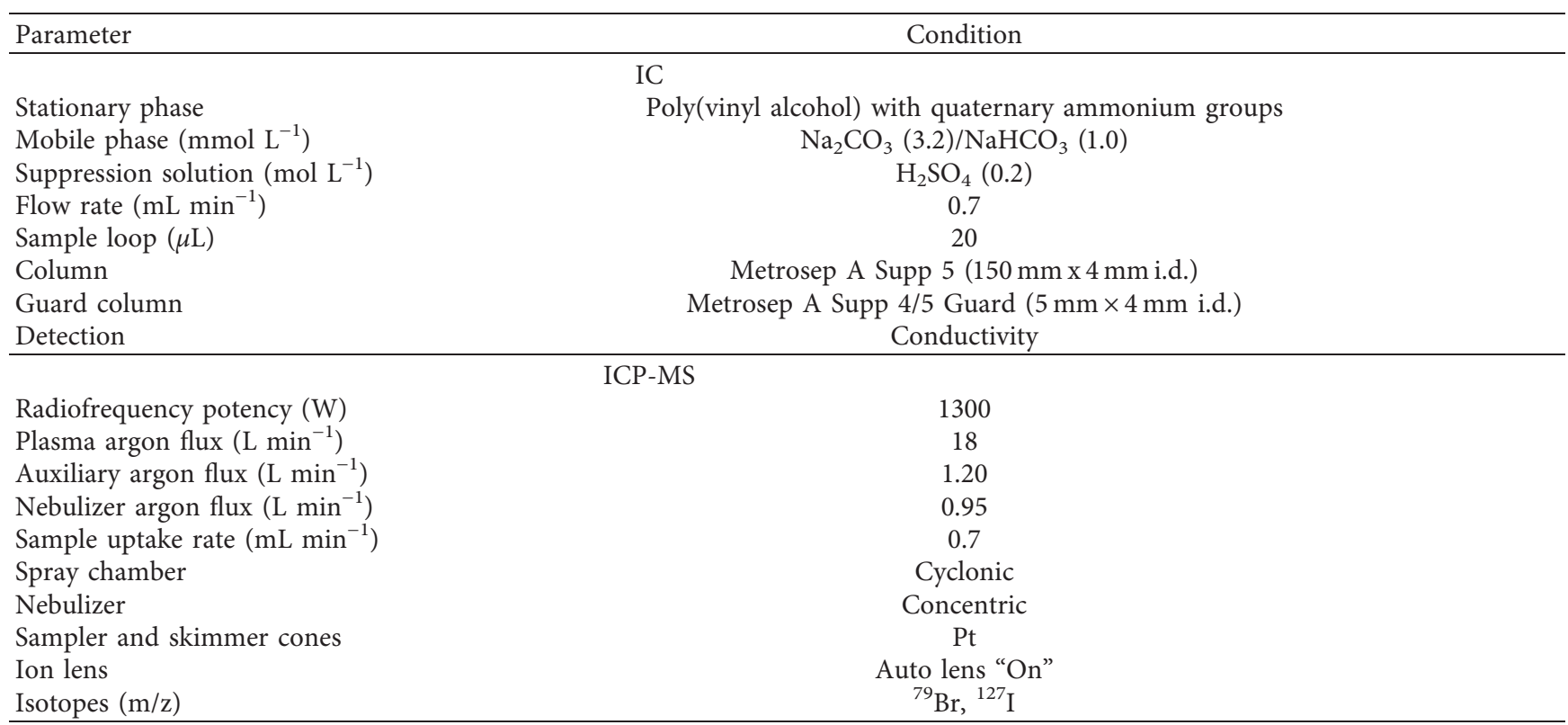

of a high sample is important to obtain better LODs and LOQs. In this sense, the sample mass of $500 \mathrm{mg}$ mixed with $50 \mu \mathrm{L}$ of $6 \mathrm{~mol} \mathrm{~L}^{-1} \mathrm{NH}_{4} \mathrm{NO}_{3}$ was selected as better condition for digestion of mushrooms by the MIC method.

3.2. Limits of Detection and Quantification. Prior to the evaluation of the absorbing solution for MIC method, the LODs and LOQs calculations were performed for each analyte and method. These limits were used to define the concentrations to be added in the samples in the recovery tests for those elements that were below the LOQ in the evaluated samples. In this sense, considering that the reagent blank values were used for the calculations, this study aimed to verify the influence caused by different absorbing solutions in the reagent blanks.

For LOD and LOQ calculation, the average of the blanks (10 readings) for each analyte plus 3 times the standard deviation (for LOD) or 10 times the standard deviation (for LOQ) were considered [33]. Furthermore, in the calculation, the dilution factor, the final volume of the digests, and the sample mass were considered. In this sense, the reagent blanks obtained after the sample preparation, using different absorbing solutions (ultrapure water and $50 \mathrm{mmol} \mathrm{L} \mathrm{L}^{-1}$, $100 \mathrm{mmol} \mathrm{L}^{-1}$, and $150 \mathrm{mmol} \mathrm{L}^{-1} \mathrm{NH}_{4} \mathrm{OH}$ ), were analyzed. For determination by IC, only the peak related to the retention time of $\mathrm{Cl}$ was detected in the chromatograms. On the other hand, an interference was observed near to the retention time of $\mathrm{F}$, while $\mathrm{Br}$ and I were not detected in the blanks because these elements were in concentrations below that detectable in the chromatograms.

Taking into account that the average of the blanks was used for LOD calculation for F, dilutions of the blanks of digestion using ultrapure water as absorbing solution were carried out with the addition of a known concentration of this element in solution $\left(0.05 \mathrm{mg} \mathrm{L}^{-1}\right)$ until the absence of interference and obtaining an adequate recovery. In view of this, it was observed that, after a dilution factor of 5 times, suitable recovery and no interference were observed. Thus, this dilution factor, as well as the results obtained from the analyses previously mentioned, was considered for LOD and LOQ calculation. The LOD and LOQ for F were, respectively, $23 \mathrm{mg} \mathrm{kg}^{-1}$ and $30 \mathrm{mg} \mathrm{kg}^{-1}$. For Br and I, LODs were performed considering the baseline noise for the retention time of these elements. Thus, a LOD of $6 \mathrm{mg} \mathrm{kg}^{-1}$ and $24 \mathrm{mg} \mathrm{kg}^{-1}$ and a LOQ of $7 \mathrm{mg} \mathrm{kg}^{-1}$ and $61 \mathrm{mg} \mathrm{kg}^{-1}$ for $\mathrm{Br}$ and I, respectively, were obtained.

On the other hand, interference was observed in the $\mathrm{Cl}$ retention time, possibly due to the use of $100 \mathrm{mmol} \mathrm{L}^{-1} \mathrm{NH}_{4} \mathrm{OH}$ as absorbing solution, as shown in Figure 1. Thus, dilutions of the blanks were carried out with the addition of a known concentration of $\mathrm{Cl}\left(0.1 \mathrm{mg} \mathrm{L}^{-1}\right)$ until the absence of interference and an adequate recovery; therefore, a dilution of 4 times was needed. In this sense, different values of LOD and LOQ for $\mathrm{Cl}$ were obtained, as shown in Table 2. Based on Table 2, when using $100 \mathrm{mmol} \mathrm{L}^{-1} \mathrm{NH}_{4} \mathrm{OH}$ solution, it was possible to observe an increase of about 4 times for LOD and LOQ.

The LODs and LOQs for $\mathrm{Br}$ and I by ICP-MS were considerably lower than those obtained by IC, as can be observed in Table 2, ranging from 88 times to 3000 times lower than those obtained by IC, using the different absorbing solutions evaluated. This decrease in LOD values demonstrates that ICP-MS has a greater sensitivity for determination of these elements. In addition, it is worth mentioning that when increasing the concentration of the absorbing solution, the LODs for $\mathrm{Br}$ also increased, possibly because the solution has better absorption characteristics of the analyte. On the other hand, for I, this behavior was not observed, since in increasing the concentration of the absorbing solution, no significant increases were observed in the LODs or LOQs. 


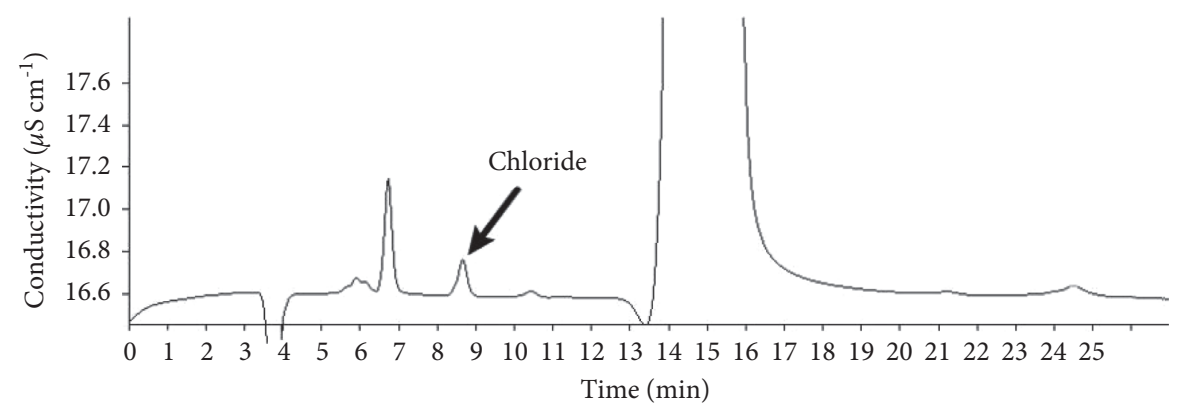

(a)

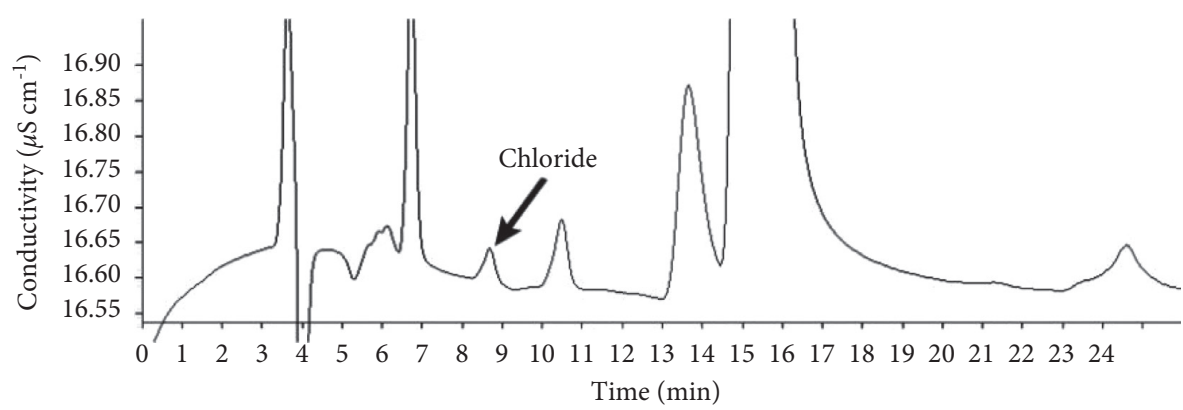

(b)

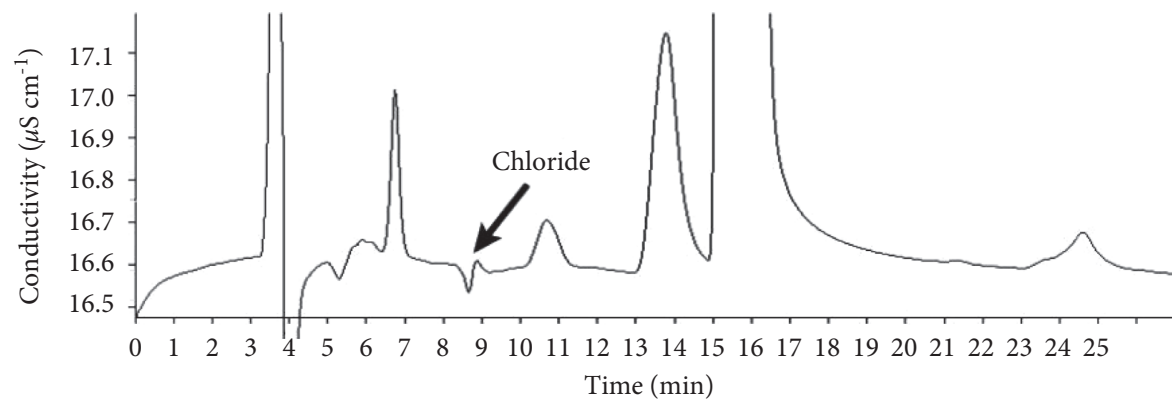

(c)

FIGURE 1: Chromatograms of the blanks using (a) ultrapure water, (b) $50 \mathrm{mmol} \mathrm{L}^{-1} \mathrm{NH}_{4} \mathrm{OH}$, and (c) $100 \mathrm{mmol} \mathrm{L}^{-1} \mathrm{NH}_{4} \mathrm{OH}$ as absorbing solution.

TABLE 2: Limits of detection and quantification for chlorine by IC and for bromine and iodine by ICP-MS, using different absorbing solutions for sample preparation of mushrooms $(500 \mathrm{mg})$ by MIC.

\begin{tabular}{|c|c|c|c|c|c|c|}
\hline \multirow{2}{*}{ Absorbing solution } & \multicolumn{3}{|c|}{ LOD $\left(\mathrm{mg} \mathrm{kg}^{-1}\right)$} & \multicolumn{3}{|c|}{ LOQ $\left(\mathrm{mg} \mathrm{kg}^{-1}\right)$} \\
\hline & Chlorine & Bromine & Iodine & Chlorine & Bromine & Iodine \\
\hline Ultrapure water & 9 & 0.005 & 0.008 & 17 & 0.019 & 0.012 \\
\hline $50 \mathrm{mmol} \mathrm{L}^{-1} \mathrm{NH}_{4} \mathrm{OH}$ & 10 & 0.040 & 0.014 & 18 & 0.069 & 0.016 \\
\hline $100 \mathrm{mmol} \mathrm{L}^{-1} \mathrm{NH}_{4} \mathrm{OH}$ & 40 & 0.066 & 0.014 & 74 & 0.096 & 0.015 \\
\hline $150 \mathrm{mmol} \mathrm{L}^{-1} \mathrm{NH}_{4} \mathrm{OH}$ & $\mathrm{Nd}^{*}$ & 0.068 & 0.014 & $\mathrm{Nd}^{*}$ & 0.099 & 0.016 \\
\hline
\end{tabular}

${ }^{*}$ Not determined.

3.3. Evaluation of the Absorbing Solutions for Halogens. In order to obtain accurate results, different absorbing solutions were evaluated to choose the better solution for halogen absorption. Thus, for IC analysis, ultrapure water and $\mathrm{NH}_{4} \mathrm{OH}$ solutions $\left(50 \mathrm{mmol} \mathrm{L}^{-1}\right.$ and $100 \mathrm{mmol} \mathrm{L}^{-1}$ ) were evaluated and, for ICP-MS analysis, ultrapure water and $\mathrm{NH}_{4} \mathrm{OH}$ solutions $\left(50 \mathrm{mmol} \mathrm{L}^{-1}, 100 \mathrm{mmol} \mathrm{L}^{-1}\right.$, and $150 \mathrm{mmol} \mathrm{L}^{-1}$ ) were evaluated. The absorbing solutions used in this study were selected considering previous studies that recommend these solutions for halogens [30, 32, 34]. For this evaluation, recovery tests were performed by addition of a known analyte concentration (corresponding to $50 \%$ of the obtained concentration in the sample used for optimization) in the sample for each absorbing solution evaluated. The standard solution was added in the samples prior the digestion by MIC method.

During the determination of halogens by IC, it was observed that only $\mathrm{Cl}$ could be determined, while $\mathrm{Br}$ and I 
were below the LOD. For F, interference was observed in the same retention time of this analyte, making it necessary to perform dilutions to enable the determinations. Taking into account these facts, for $\mathrm{Br}, \mathrm{F}$, and I, the recovery tests were performed by the addition of known concentrations of these elements (1.5 times the concentration obtained for the LOQs of each analyte (Section 3.2). The recoveries for all analytes are shown in Figure 2.

As shown in Figure 2, suitable recoveries for $\mathrm{Cl}$ and $\mathrm{F}$ in all absorbing solutions evaluated were obtained, with recoveries ranging from $97 \%$ to $103 \%$ and relative standard deviations (RSDs) lower than 6\%. In this sense, it is important to point out that no significant differences (ANOVA, confidence level of 95\%) were observed for $\mathrm{Cl}$ and $\mathrm{F}$ recoveries using all absorbing solutions. However, for $\mathrm{Br}$ and $\mathrm{I}$, unsuitable recoveries were obtained, $67 \%$ and $89 \%$ for $\mathrm{Br}$ and $22 \%$ and $77 \%$ for I, when using, respectively, ultrapure water and $50 \mathrm{mmol} \mathrm{L}^{-1} \mathrm{NH}_{4} \mathrm{OH}$. In contrast, suitable recoveries ( $95 \%$ for $\mathrm{Br}$ and $97 \%$ for I) were obtained using $100 \mathrm{mmol} \mathrm{L}^{-1} \mathrm{NH}_{4} \mathrm{OH}$ solution, with RSDs lower than $8 \%$. Moreover, when evaluating the $\mathrm{pH}$ of the diluted digests, values below 5.8 were observed for ultrapure water and $50 \mathrm{mmol} \mathrm{L}^{-1} \mathrm{NH}_{4} \mathrm{OH}$, while when $100 \mathrm{mmol} \mathrm{L}^{-1} \mathrm{NH}_{4} \mathrm{OH}$ was used a $\mathrm{pH}$ of 7.6 was observed. It is important to point out that alkaline solutions lead to better halogen stabilization, as demonstrated in other studies [28, 35].

In view of the suitable recoveries for all halogens by IC, the $100 \mathrm{mmol} \mathrm{L}^{-1} \mathrm{NH}_{4} \mathrm{OH}$ was selected as method condition. This fact corroborates with some studies reported in the literature, which mention that $100 \mathrm{mmol} \mathrm{L}^{-1} \mathrm{NH}_{4} \mathrm{OH}$ is a suitable solution for further halogen determination by IC $[26,31,36]$.

However, aiming at lower reagent consumption, as well as a higher practicality in the sample preparation, it is important to highlight that the use of ultrapure water allowed a suitable $\mathrm{Cl}$ and $\mathrm{F}$ absorption, which can be noted in the suitable recoveries for these analytes. Moreover, ultrapure water as absorbing solution showed lower LODs for $\mathrm{Cl}$ regarding to the other solutions evaluated.

Taking into account that it was not possible to determine $\mathrm{Br}$ and I in the samples by IC due to its low concentration, this determination was performed by ICP-MS. The choice of this technique was due its higher sensitivity for $\mathrm{Br}$ and I when compared to the IC analysis [17]. Moreover, when comparing the LODs between both techniques, it is possible to observe a considerable difference in the values. Thus, a recovery test with the addition of a known concentration of $\mathrm{Br}$ and $\mathrm{I}$ in the sample prior to the digestion by MIC was performed. The concentration of the solution added in the sample corresponded to $75 \%$ of the concentration of $\mathrm{Br}$ in the analyzed samples and 2 times the LOQ obtained for I by ICP-MS, in view that concentration for I, in the analyzed sample, was below the LOQ. The results of the recovery tests are shown in Figure 3.

As shown in Figure 3, suitable recoveries for $\mathrm{Br}$ and I were observed using all absorbing solutions, ranging from $97 \%$ to $108 \%$ for $\mathrm{Br}$ and from $98 \%$ to $110 \%$ for I. When evaluating the different absorbing solutions, no significant differences (ANOVA, confidence level of 95\%) were observed for both analytes.

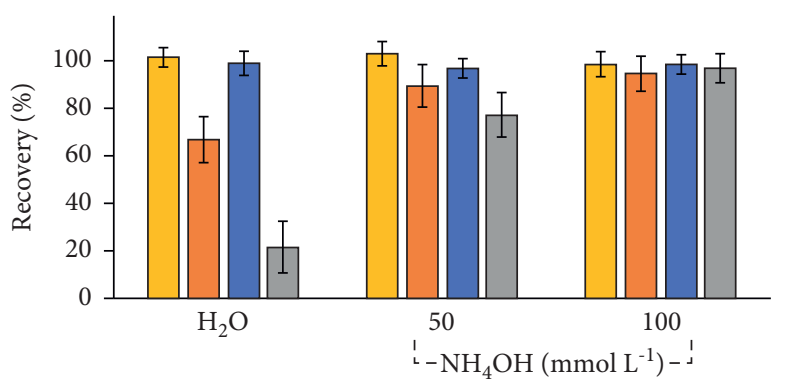

Absorbing solution

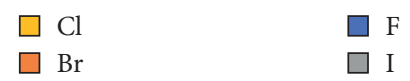

FIgURE 2: Recoveries obtained by IC for chlorine after the addition of $50 \%$ of the concentration obtained in the samples and for bromine, fluorine, and iodine after the addition of 1.5 times the concentration of the LOQs for each element $(n=3)$.
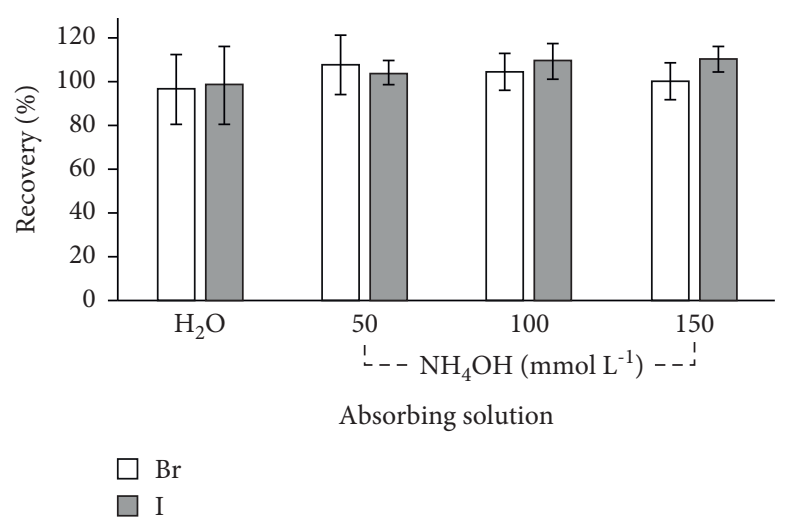

FIgURE 3: Recoveries obtained by ICP-MS for bromine and iodine in mushrooms digested by MIC after the addition of $75 \%$ of bromine concentration and 2 times the LOQ for iodine $(n=3)$.

Moreover, the $\mathrm{pH}$ values of the digests were evaluated and only $100 \mathrm{mmol} \mathrm{L}^{-1}$ and $150 \mathrm{mmol} \mathrm{L}^{-1} \mathrm{NH}_{4} \mathrm{OH}$ solutions presented slightly alkaline values (7.6 and 8.2, respectively). Thus, in view of the suitable recoveries, $100 \mathrm{mmol} \mathrm{L}^{-1} \mathrm{NH}_{4} \mathrm{OH}$ solution was selected as the most suitable condition to absorb $\mathrm{Br}$ and I for subsequent analysis by ICP-MS. Moreover, it is important to mention that though the solution of $150 \mathrm{mmol} \mathrm{L}^{-1} \mathrm{NH}_{4} \mathrm{OH}$ did not present significant differences regarding the $100 \mathrm{mmol} \mathrm{L}^{-1} \mathrm{NH}_{4} \mathrm{OH}$ for $\mathrm{Br}$ and I concentrations, the lower concentration was selected in view of the lower reagent consumption.

For the trueness evaluation of the proposed method for $\mathrm{Cl}$ determination by IC and $\mathrm{Br}$ and I determination by ICPMS, the RM NIST 8435 was also used. A suitable trueness for $\mathrm{Cl}$ by IC was observed, with recoveries of $102 \%$ between spiked value $\left(843 \mathrm{mg} \mathrm{kg}^{-1}\right)$ and the recovered value $\left(856 \pm 6 \mathrm{mg} \mathrm{kg}^{-1}\right)$. However, recoveries of $87 \%$ for $\mathrm{Br}$ and $86 \%$ for I by ICP-MS were observed, where the values spiked were $2.00 \mathrm{mg} \mathrm{kg}^{-1}$ for $\mathrm{Br}$ and $0.23 \mathrm{mg} \mathrm{kg}^{-1}$ for I, while the recovered values were $1.74 \pm 0.09 \mathrm{mg} \mathrm{kg}^{-1}$ for $\mathrm{Br}$ and $0.20 \pm 0.01 \mathrm{mg} \mathrm{kg}^{-1}$ for I. The lower recoveries for these 
analytes can be related to the high standard deviation (SD) presented by the RM certificate. The RSDs for the reference concentrations of $\mathrm{Br}$ and $\mathrm{I}$ in the RM NIST 8435 are $50 \%$ and $17 \%$, respectively. Moreover, though the RM present values for Br, F, and I, its determination was not possible by IC due the lower concentration of these elements in the material.

3.4. Determination of Halogens in Mushrooms. After the choice of the more suitable sample preparation conditions and the accuracy evaluation of the proposed methods, the analysis of the other mushrooms species was performed. The results regarding to determination of $\mathrm{Br}, \mathrm{Cl}, \mathrm{F}$, and I by IC in the samples are shown in Table 3.

As observed in Table 3, using IC, only $\mathrm{Cl}$ concentration was possible to be determined in the samples evaluated, in view that $\mathrm{Br}, \mathrm{F}$, and I concentrations were below the LODs. For $\mathrm{Cl}$, a large range of concentration (from $523 \mathrm{mg} \mathrm{kg}^{-1}$ to $13053 \mathrm{mg} \mathrm{kg}^{-1}$ ) was observed, in which the Champignon species presented the higher values. The variation in $\mathrm{Cl}$ concentration possibly is related to the nutrients added in the cultivation of different species of mushrooms [5].

According to the daily intake of $\mathrm{Cl}$ recommended by the Institute of Medicine of the National Academies of Science (Washington, USA), an adult who is between 19 and 50 years old should receive an intake of $2300 \mathrm{mg}$ of $\mathrm{Cl}$ daily with the goal of obtaining a good functioning level of the body [37]. Although the values for $\mathrm{Cl}$ in the samples evaluated are considered high, it is important to emphasize that the concentration is related to dry base. Thus, when considering the dry mushrooms, about $177 \mathrm{~g}$ of White Champignon provides the recommended daily intake of $\mathrm{Cl}$. However, when Shimeji mushroom is ingested, about $4.4 \mathrm{~kg}$ is necessary to provide the daily recommended intake of $\mathrm{Cl}$. It is important to point out that these correlations are based on a daily diet of only mushroom.

In Table 4, the $\mathrm{Br}$ and I concentrations determined by ICP-MS after digestion by the MIC method of the different species of mushrooms are shown.

As shown in Table 4, it is possible to observe that $\mathrm{Br}$ concentration in all the samples evaluated was higher than the LOD $\left(0.066 \mathrm{mg} \mathrm{kg}^{-1}\right)$, varying in a small concentration range $\left(2.49 \mathrm{mg} \mathrm{kg}^{-1}\right.$ to $\left.5.50 \mathrm{mg} \mathrm{kg}^{-1}\right)$. In this context, taking into account that $\mathrm{Br}$ has no daily intake recommendation, it is not possible to estimate if the concentration of this element is suitable for the human consumption. For I, it was possible to observe that only one sample (White Champignon) showed concentration below the LOD $\left(0.014 \mathrm{mg} \mathrm{kg}^{-1}\right)$. However, for the other samples, a small variation in the I concentration was observed (from $0.019 \mathrm{mg} \mathrm{kg}^{-1}$ to $0.047 \mathrm{mg} \mathrm{kg}^{-1}$ ).

According to the daily intake of I recommended by the Third National Health and Nutrition Examination Survey (Georgia, USA), an adult should have an intake of $140 \mu \mathrm{g}$ of I daily with the goal of obtaining a good functioning level of the body [37]. Taking into account that the values for I in the samples evaluated are low, when considered the intake only of dry mushrooms, about $3 \mathrm{~kg}$ of Shimeji (sample with higher concentration of I) would be needed to provide the daily recommended intake of $\mathrm{I}$.
TABle 3: Concentration of halogens in mushrooms (dry base; $500 \mathrm{mg}$ ) after digestion by the MIC method using $100 \mathrm{mmol} \mathrm{L}^{-1} \mathrm{NH}_{4} \mathrm{OH}$ as absorbing solution and determination by IC (mean \pm standard deviation; $n=3$ ).

\begin{tabular}{lcccc}
\hline \multirow{2}{*}{ Mushroom } & \multicolumn{4}{c}{ Concentration $\left(\mathrm{mg} \mathrm{kg}^{-1}\right)$} \\
& Bromine & Chlorine & Fluorine & Iodine \\
\hline Brown Champignon & $<6^{*}$ & $9861 \pm 1017$ & $<23^{*}$ & $<24^{*}$ \\
White Champignon & $<6^{*}$ & $13053 \pm 216$ & $<23^{*}$ & $<24^{*}$ \\
Shiitake & $<6^{*}$ & $529 \pm 77$ & $<23^{*}$ & $<24^{*}$ \\
Shimeji & $<6^{*}$ & $523 \pm 37$ & $<23^{*}$ & $<24^{*}$ \\
\hline
\end{tabular}

${ }^{*}$ Limit of detection.

TABLE 4: Concentration of bromine and iodine in mushrooms (dry base; $500 \mathrm{mg}$ ) after digestion by the MIC method using $100 \mathrm{mmol} \mathrm{L}^{-1} \mathrm{NH}_{4} \mathrm{OH}$ as absorbing solution and determination by ICP-MS (mean \pm standard deviation; $n=3$ ).

\begin{tabular}{lcc}
\hline \multirow{2}{*}{ Mushroom } & \multicolumn{2}{c}{ Concentration $\left(\mathrm{mg} \mathrm{kg}^{-1}\right)$} \\
& Bromine & Iodine \\
\hline Brown Champignon & $5.50 \pm 0.37$ & $0.040 \pm 0.002$ \\
White Champignon & $4.31 \pm 0.09$ & $<0.014^{*}$ \\
Shiitake & $2.49 \pm 0.10$ & $0.019 \pm 0.001$ \\
Shimeji & $3.40 \pm 0.48$ & $0.047 \pm 0.007$ \\
\hline
\end{tabular}

${ }^{*}$ Limit of detection.

TABLE 5: Concentration range for bromine, chlorine, and iodine in mushrooms reported in the literature and in the samples analyzed in this study.

\begin{tabular}{lccc}
\hline \multirow{2}{*}{ Reference } & \multicolumn{3}{c}{ Concentration $\left(\mathrm{mg} \mathrm{kg}^{-1}\right)$} \\
& Bromine & Chlorine & Iodine \\
\hline$[14]$ & $0.24-177$ & $74-26774$ & $\mathrm{Nd}$ \\
{$[38]$} & $\mathrm{Nd}$ & $\mathrm{Nd}$ & $0.044-0.43$ \\
{$[6]$} & $0.13-2.7$ & $\mathrm{Nd}$ & $\mathrm{Nd}$ \\
{$[15]$} & $4.2-27.2$ & $\mathrm{Nd}$ & $\mathrm{Nd}$ \\
This study & $2.49-5.50$ & $523-13053$ & $<0.014^{*}-0.047$
\end{tabular}

* Limit of detection; Nd: not determined.

The results obtained for $\mathrm{Br}, \mathrm{Cl}$, and $\mathrm{I}$ in this study were compared to those reported in the literature for mushrooms of different species $[6,14,15,38]$. Based on the concentration ranges for these elements presented in Table 5, it can be observed that the values for $\mathrm{Br}, \mathrm{Cl}$, and I are within those reported in the literature. These variations between the values can be related to the different species of mushrooms evaluated in the works, as well as their different origins and type of cultivation.

\section{Conclusion}

In view of the results obtained during this study, it was possible to conclude that the developed method was suitable for the determination of halogens in mushrooms after decomposition by MIC and subsequent determination by IC, as well as determination of Br and I by ICP-MS. In addition, the proposed method showed a high sample throughput. Furthermore, this method provided the use of diluted 
reagents, reducing reagent consumption during the analyses and compatible digests for both the determination techniques.

In view of the application of the method using IC, it was not possible to determine $\mathrm{Br}, \mathrm{F}$, and I because the concentrations were below the LODs. On the other hand, using ICP-MS it was possible to determine $\mathrm{Br}$ in all the samples evaluated and I in the majority of the samples, and a small variation in the concentration of these analytes was observed between the different species of mushroom.

Moreover, it should be noted that although it was not possible to perform the determination of some elements by IC, due to the low concentrations in the mushrooms, the developed method presented good accuracy for all the elements. Finally, it is possible to highlight the potential of the use of MIC for the sample preparation of mushroom, the use of IC for the determination of halogens, and the ICP-MS especially for the determination of $\mathrm{Br}$ and $\mathrm{I}$, as well as the compatibility of digests obtained by MIC with different determination techniques.

\section{Data Availability}

The data used to support the findings of this study are available at Theses \& Dissertations Catalog (CAPES), Brazil (https://sucupira.capes.gov.br/sucupira/public/consultas/ coleta/trabalhoConclusao/viewTrabalhoConclusao.jsf? popup=true\&id_trabalho=5685136).

\section{Conflicts of Interest}

The authors declare that they have no conflicts of interest.

\section{Acknowledgments}

This study was financed in part by the Coordenação de Aperfeiçoamento de Pessoal de Nível Superior (CAPESBrazil) under Finance Code 001. The authors are also grateful to Conselho Nacional de Desenvolvimento Científico e Tecnológico (CNPq-Brazil), under grant nos. 409357/2016-2, 309424/2016-0, and 312843/2020-8, INCTBio (Proc. Nr. 573672/2008-3), and Fundação de Amparo à Pesquisa do Estado do Rio Grande do Sul (FAPERGS-Brazil), under grant nos. 16/2551-0000561-8 and 19/2551-00011866-5, for supporting this study.

\section{References}

[1] L. Rácz, L. Papp, B. Prokai, and Z. Kovács, “Trace element determination in cultivated mushrooms: an investigation of manganese, nickel, and cadmium intake in cultivated mushrooms using ICP atomic emission," Microchemical Journal, vol. 54, no. 4, pp. 444-451, 1996.

[2] B. A. Wani, R. H. Bodha, and A. H. Wani, "Nutritional and medicinal importance of mushrooms," Journal of Medicinal Plants Research, vol. 4, pp. 2598-2604, 2010.

[3] A. F. Urben, H. C. B. Oliviera, W. Vieira, M. J. Correia, and A. H. Uriartt, Produção de cogumelos por meio de tecnologia chinesa modificada, p. 151, Brasília: Embrapa, Brasil, 2001.

[4] ANPC Associação Nacional dos Produtores de Cogumelos, Cogumelos no brasil, ANPC Associação Nacional dos
Produtores de Cogumelos, São José dos Pinhais, Brazil, 2013, https://www.anpccogumelos.org/.

[5] S. Chang and P. G. Miles, Mushrooms Cultivation, Nutritional Value, Medicinal Effect, and Environmental Impact, CRC Press, Boca Raton, FL, USA, 2004.

[6] P. L. C. Moura, A. Maihara, L. P. Castro, and R. C. L. Figueira, "Essential trace elements in edible mushrooms by neutron activation analysis," International Nuclear Atlantic Conference - INAC, 2007.

[7] A. S. McCall, C. F. Cummings, G. Bhave, R. Vanacore, A. Page-McCaw, and B. G. Hudson, "Bromine is an essential trace element for assembly of collagen IV scaffolds in tissue development and architecture," Cell, vol. 157, no. 6, pp. 1380-1392, 2014.

[8] A. B. Deangelo, M. H. George, S. R. Kilburn, T. M. Moore, and D. C. Wolf, "Carcinogenicity of potassium bromate administered in the drinking water to male B6C3F1 mice and F344/N rats," Toxicologic Pathology, vol. 26, no. 5, pp. 587-594, 1998.

[9] M. Vobecky, A. Babicky, and J. Lener, "Effect of increased bromide intake on iodine excretion in rats," Biological Trace Element Research, vol. 55, no. 3, pp. 215-219, 1996.

[10] WHO, Trace Elements in Human Nutrition and Health, World Health Organization, Geneva, Switzerland, 1996.

[11] V. R. Preed, Fluorine Chemistry, Analysis, Function and Effects, The Royal Society of Chemistry, Cambridge, UK, 2015.

[12] WHO, Assessment of Iodine Deficiency Disorders and Monitoring Their Elimination - a Guide for Programme Managers, World Health Organization, Geneva Switzerland, 2007.

[13] M. B. Zimmermann, P. L. Jooste, and C. S. Pandav, "Iodinedeficiency disorders," The Lancet, vol. 372, no. 9645, pp. 1251-1262, 2008.

[14] Z. Randa and J. Kucera, "Trace elements in higher fungi (mushrooms) determined by activation analysis," Journal of Radioanalytical and Nuclear Chemistry, vol. 259, pp. 99-107, 2004.

[15] Ş. Turhan, A. Zararsız, and H. Karabacak, "Determination of element levels in selected wild mushroom species in Turkey using non-destructive analytical techniques," International Journal of Food Properties, vol. 13, no. 4, pp. 723-731, 2010.

[16] X. Bu, T. Wang, and G. Hall, "Determination of halogens in organic compounds by high resolution inductively coupled plasma mass spectrometry (HR-ICP-MS)," Journal of Analytical Atomic Spectrometry, vol. 18, no. 12, pp. 1443-1451, 2003.

[17] P. A. Mello, J. S. Barin, F. A. Duarte et al., "Analytical methods for the determination of halogens in bioanalytical sciences: a review," Analytical and Bioanalytical Chemistry, vol. 405, no. 24, pp. 7615-7642, 2013.

[18] P. Manzi, L. Gambelli, S. Marconi, V. Vivanti, and L. Pizzoferrato, "Nutrients in edible mushrooms: an interspecies comparative study," Food Chemistry, vol. 65, no. 4, pp. 477-482, 1999.

[19] D. La Rosa Novo, R. M. Pereira, A. S. Henn, V. C. Costa, E. M. Moraes Flores, and M. F. Mesko, "Are there feasible strategies for determining bromine and iodine in human hair using interference-free plasma based-techniques?" Analytica Chimica Acta, vol. 1060, pp. 45-52, 2019a.

[20] J.-L. Todolí and J.-M. Mermet, "Acid interferences in atomic spectrometry: analyte signal effects and subsequent reduction," Spectrochimica Acta Part B: Atomic Spectroscopy, vol. 54, pp. 895-929, 1999.

[21] G. S. Coelho Junior, C. A. Hartwig, I. G. Toralles et al., "Determination of $\mathrm{Cl}$ and $\mathrm{S}$ in edible seaweed by ion chromatography after decomposition by microwave-induced 
combustion," Revista Virtual de Química, vol. 9, pp. 492-501, 2017.

[22] P. d. A. Mello, C. K. Giesbrecht, M. S. Alencar et al., "Determination of sulfur in petroleum coke combining closed vessel microwave-induced combustion and inductively coupled plasma-optical emission spectrometry," Analytical Letters, vol. 41, no. 9, pp. 1623-1632, 2008.

[23] J. E. de Mello, D. L. R. Novo, G. S. Coelho Junior, M. F. Mesko, and M. F. Mesko, "A green analytical method for the multielemental determination of halogens and sulfur in pet food," Food Analytical Methods, vol. 13, no. 1, pp. 131-139, 2020.

[24] M. F. Mesko, F. P. Balbinot, P. T. Scaglioni, M. S. Nascimento, R. S. Picoloto, and V. C. da Costa, "Determination of halogens and sulfur in honey: a green analytical method using a single analysis," Analytical and Bioanalytical Chemistry, vol. 412, no. 24, pp. 6475-6484, 2020.

[25] M. F. Mesko, V. C. Costa, R. S. Picoloto, C. A. Bizzi, and P. A. Mello, "Halogen determination in food and biological materials using plasma-based techniques: challenges and trends of sample preparation," Journal of Analytical Atomic Spectrometry, vol. 31, no. 6, pp. 1243-1261, 2016 a.

[26] M. F. Mesko, I. G. Toralles, C. A. Hartwig et al., "Bromine and iodine contents in raw and cooked shrimp and its parts," Journal of Agricultural and Food Chemistry, vol. 64, no. 8, pp. 1817-1822, 2016b.

[27] S. V. da Silva, R. S. Picoloto, E. M. M. Flores, R. Wagner, N. S. P. dos Santos Richards, and J. S. Barin, "Evaluation of bromine and iodine content of milk whey proteins combining digestion by microwave-induced combustion and ICP-MS determination," Food Chemistry, vol. 190, pp. 364-367, 2016.

[28] V. C. Costa, R. S. Picoloto, C. A. Hartwig, P. A. Mello, E. M. M. Flores, and M. F. Mesko, "Feasibility of ultra-trace determination of bromine and iodine in honey by ICP-MS using high sample mass in microwave-induced combustion," Analytical and Bioanalytical Chemistry, vol. 407, no. 26, pp. 7957-7964, 2015.

[29] D. L. R. Novo, J. E. Mello, F. S. Rondan, A. S. Henn, P. A. Mello, and M. F. Mesko, "Bromine and iodine determination in human saliva: challenges in the development of an accurate method," Talanta, vol. 191, pp. 415-421, $2019 \mathrm{~b}$.

[30] F. S. Rondan, C. A. Hartwig, D. L. R. Novo et al., "Ultra-trace determination of bromine and iodine in rice by ICP-MS after microwave-induced combustion," Journal of Food Composition and Analysis, vol. 66, pp. 199-204, 2018.

[31] I. G. Toralles, G. S. Coelho Jr., V. C. Costa, S. M. Cruz, E. M. M. Flores, and M. F. Mesko, "A fast and feasible method for $\mathrm{Br}$ and I determination in whole egg powder and its fractions by ICP-MS," Food Chemistry, vol. 221, pp. 877-883, 2017.

[32] F. S. Rondan, G. S. Coelho Junior, A. S. Henn, E. I. Muller, M. F. Mesko, and M. F. Mesko, "A versatile green analytical method for determining chlorine and sulfur in cereals and legumes," Food Chemistry, vol. 285, pp. 334-339, 2019.

[33] Eurachem Guide, The Fitness for Purpose of Analytical Methods - A Laboratory Guide to Method Validation and Related Topics, 2 edition, 2014, http://www.eurachem.org.

[34] R. M. Pereira, V. C. Costa, C. A. Hartwig et al., "Feasibility of halogen determination in noncombustible inorganic matrices by ion chromatography after a novel volatilization method using microwave-induced combustion," Talanta, vol. 147, pp. 76-81, 2016.

[35] M. F. Mesko, I. G. Toralles, J. Coelho et al., "Ion chromatography coupled to mass spectrometry as a powerful technique for halogens and sulfur determination in egg powder and its fractions," Rapid Communications in Mass Spectrometry, vol. 34, p. e8775, 2020.

[36] J. S. Silva, L. O. Diehl, A. C. Frohlich et al., "Determination of bromine and iodine in edible flours by inductively coupled plasma mass spectrometry after microwave-induced combustion," Microchemical Journal, vol. 133, pp. 246-250, 2017.

[37] J. J. Otten, J. P. Hellwig, and L. D. Meyers, Dietary Reference Intakes: The Essential Guide to Nutrient Requirements, $\mathrm{Na}$ tional Academies Press, Washington, DC, USA, 1st edition, 2006.

[38] M. Haldimann, A. Alt, A. Blanc, and K. Blondeau, "Iodine content of food groups," Journal of Food Composition and Analysis, vol. 18, no. 6, pp. 461-471, 2005. 